\title{
Telling Narratives: The Practice of Mapping Space in Pre-Service Art Education Practicum
}

\section{Contando Histórias: a prática de mapear o espaço nos estágios supervisionados em arte-educação}

\begin{abstract}
Teacher education programs need to continually adapt to changes in licensure requirements as well as technological advances. This author advances an ethnographic approach to fieldwork that utilizes Google Maps programs to visually represent the collected data and subsequent reflections on their experiences in urban schools. This particular case draws from scholarship in the fields of narrative inquiry, critical cartography and the works of Michel de Certeau to analyze the data collected during the study and draws related implications for the field of art education.

Keywords: Ethnography. Narrative Inquiry. Teacher Education. Cartography.

Resumo: Os programas de formação de professores precisam se adaptar continuamente às mudanças nos requisitos de licenciamento, bem como os avanços tecnológicos. Este autor apresenta uma abordagem etnográfica para o trabalho de campo que utiliza programas do Google Maps para representar visualmente os dados recolhidos e reflexões posteriores sobre as suas experiências em escolas localizadas em centros urbanos. Este caso particular é interpretado através das bolsas de estudos nos domínios da pesquisa narrativa, cartografia crítica e das obras de Michel de Certeau, para analisar os dados recolhidos durante o estudo e faz respectivas implicações para o campo da disciplina de arte.
\end{abstract}

Palavras-chave: Etnografia. Pesquisa narrativa. Formação de professores. Cartografia.

\section{Introduction}

This study is informed by a continual, albeit non-linear, progression of professional identities: undergraduate student, student teacher, K-12 art teacher, graduate student, cooperating teacher, doctoral student, student teaching supervisor, and researcher. In additional to seven years of teaching in an inner-city school district, I spent two years teaching at an international school in São Paulo, Brazil, which revolutionized my pedagogy. This period was precipitated by two years of graduate classes prior to leaving for São Paulo. Upon my return, I commenced research towards a thesis and was encouraged by my committee to unpack the two years I spent in Brazil as well as my transition back into teaching in an American public school. The thesis took the form of a narrative that drew from prevalent art educators who wrote about issues of transience, travel, and community

SUTTERS, Justin P. Telling Narratives: The Practice of Mapping Space in Pre-Service Art Education Practicum. Informática na Educação: teoria e prática, Porto Alegre, v. 19 n. 1, p. 115-128, jan./maio 2016. 
(BALLENGEE-MORRIS; STUHR, 2001, BASTOS, 2006a, 2006b, MORRIS; MIRIN; RIZZI, 2000). My research led to an increased understanding of self, a newfound perspective towards curricula, and a heightened sense of empathy for immigrant students (SUTTERS, 2006).

Building upon both this scholarship as well as my personal experiences, my professional trajectory is now primarily focused on teacher education in academia and as such, I am primarily concerned with field practices in urban ${ }^{1}$ and/or inner-city schools prior to student teaching and how these formative experiences can be more effectively utilized as contested spaces. I implement pedagogical strategies that encourage reflexivity through ethnographic field practices and the documentation of disruptive stories that occur during their observations at regional public schools. I theorize that a narrative told by a teaching candidate $(\mathrm{TC})^{2}$ of a critical incident is not a mere recounting of an objective, isolated occurrence. Rather, I advance a practice that critically examines their story-telling as reproduction that reveals the socio-cultural construction of their disposition. The objective of this research is to examine the narratives - written, spoken, and visual - of a pre-service student as spatial mapping so as to isolate not only what is represented, but also what is left out through erasure (CRAMPTON, 2010, KITCHIN; DODGE, 2007). I encourage an ethnographic approach to know the site and the surrounding space, and also the route that was taken to get there. Navigation, or the process of traveling can be seen as a way of knowing (CERTEAU, 2002).

\section{Research Design}

The following paper stems from an IRB ${ }^{3}$ approved doctoral dissertation (SUTTERS, 2012) that involved multiple participants. Since the conclusion of that study, I have continued to work specifically with one of the participants and we presented longitudinal implications at the National Art Education Association (NAEA) conference thereafter. The specific methodologies enacted in that study are outlined within the larger study, but for the purposes of this particular paper, I adopt a methodology informed by Case Study Research (CSR) and Narrative Inquiry (NI) to further analyze the responses of one participant during the study and their reflections and observations since.

A small sample size can understandably lead to questions of validity and generalizability. Flyvbjerg (2006, p. 235) says one of the advantages of the case study "[...] is that it can 'close in' on real-life situations and test views directly in relation to phenomena as they unfold in practice $[\ldots]$ ". Schwandt defines a case study as when "[...] the object of study is a contemporary phenomenon in a real-life context, when boundaries between the phenomenon and the context are not clear, and when it is desirable to use multiple sources of evidence $[\ldots]^{\prime \prime}$ (SCHWANDT, 2007, p. 28). It is not plausible to claim that one case study could reveal or drastically alter the complexity of issues pertaining to teacher education. However, Flyvbjerg (2006) advances the notion that case studies produce theory and can help in clarifying the deeper causes behind an issue instead of just descri-

\footnotetext{
${ }^{1}$ In American schools, the terms urban and inner-city are often used synonymously, and erroneously as they both are loaded signifiers associated with lower socio-economic schools serving predominantly minority populations.

2 Cognizant of the varied approaches individuals take towards licensure, I have generalized those in teacher education programs through a signifier that encapsulates anyone whom still is actively engaged in academic studies and has not yet fully entered into the workforce as an art educator.

${ }^{3}$ This study was approved by the Institutional Review Board of the Ohio State University: Protocol \#2011B0554.
} 
bing its symptoms. Therefore, the focus of this study is to analyze a particular case through a more focused theoretical lens in order to generate practical strategies for teacher education programs.

\subsection{Methods}

As a participant in the study, Tom ${ }^{4}$ emailed me his final paper from a previous class that provided some contextual background as well as the exploration of various social issues investigated through the coursework. In the course he was enrolled in during this study, Tom was placed at an inner-city school district to conduct observations over a 10-week period. I sent Tom a Pre-Visit Worksheet and asked him to respond to the four questions in order to garner preconceptions of the urban school prior to his first observation.

Once he visited his site, I recorded an individual interview that lasted between 20-30 minutes. Along with the pre-scripted questions previously mentioned, I also asked him to share any narratives or experiences he saw or heard when traveling to the school or while at the site. Over the first month, I also began to have weekly meetings with the participants after a class they all attended and we discussed logistics of data collection while also sharing experiences.

During two of those sessions, I demonstrated the use of Google Maps and how to digitally document a trajectory to their site. Participants were instructed to collect as much data as possible during each trip using a variety of methods including photos, videos, GPS coordinates, time stamps, audio recordings, sketches, notes, maps, journals, etc. As per IRB guidelines, they were not allowed to take pictures on school property or of any students so their data was comprised of imagery taken either on the way to their site, from the exterior of the school or the surrounding areas. During these extended meetings, they were shown how to upload files into the Open Source Software (OSS) and were provided the autonomy to use additional media to represent their experience.

I conducted both group and individual interviews throughout the study and all sessions were recorded and personally transcribed. Their finished product was a visual representation in whichever digital media they selected. Tom used Google Maps as his means of representation and he emailed me a link to the website once it was completed. I then scheduled a final individual interview that was conducted and recorded in my office where I asked him to narrate the images and trajectory contained in his Google MapMashup. The official conclusion of the study culminated in a formal presentation to faculty and students in the Art Education department. Tom and I continued to keep in touch and he agreed to share how this approach to field work influenced subsequent coursework and student teaching.

\section{Research Methodologies and Related Literature}

As the relationship with the participant progressed, it was important to continually revisit and employ reflexive practices since this form of research is inherently relational. It was important that

\footnotetext{
${ }^{4}$ This is a pseudonym to protect the identity of the participant.
} 
the narratives students shared were accurately and ethically collected, transcribed and represented. The following section will outline the theoretical framework used to analyze the data.

\subsection{Narrative Inquiry: Taking Place}

Those that engage in narrative research are obligated to represent people's stories in a manner that is as close as possible to how they were shared (ELY, 2006). As a result of observing participants' construction and transmission of stories in the previous pilot study, I created a heuristic framework of Telling Narratives where participants engage in the process of narrative construction (telling as a gerund) but the narratives also describe what particular experiences reveal about those telling the story (telling as an adjective).

Clandinin and Rosiek position Narrative Inquiry within a pragmatic ontology that "[...] treats lived experiences as both the beginning and ending points of inquiry [...]" (CLANDININ; ROSIEK, 2006 , p. 44). By placing primacy on experience, some narrative inquirers adopt an epistemology that accepts individual accounts as legitimate knowledge.

\subsection{CSR and Narrative Inquiry: Honoring the Individual}

Perhaps the most methodologically significant relationship in this study is the interconnectedness between case study research and narrative inquiry because narrative inquiries "[...] begin with an interest in a particular phenomenon that is best understood narratively [...] then develop descriptions and interpretations of the phenomenon from the perspective of participants, researchers, and others [...]" (FLYVBJERG, 2006, p. 235). A study of a particular case can yield theoretical development that can result in new insights and inquiries that inform and dictate future trajectories of research and practice.

Case studies inherently contain a substantial element of narrative and like narrative, they "[...] approach the complexities and contradictions of real life [...]" (FLYVBJERG, 2006, p. 237). While this can be seen as problematic in terms of sample size, Flyvbgjerg makes the argument that when a narrative is hard to summarize it is not a problem but rather evidence of thick data and a "[...] particularly rich problematic [...]" (FLYVB]ERG, 2006, p. 237).

\subsection{Critical Incident Theory and Disruption}

During the pilot study ${ }^{5}$, I noticed a continue theme where students chose to share stories about specific incidents that really disrupted their previous expectations and it was these incidents that became of particular interest for the study. Critical Incident Theory (CIT) aligns with the de Certeau's questioning of the interpretation of an event (CERTEAU, 2002).

\footnotetext{
${ }^{5}$ A similar construct was enacted with participants the semester before without IRB approval in conjunction with a qualitative research course as a means of informing the subsequent study.
} 
Daniel Kain writes about The Critical Incident Technique in Research that "[...] involves asking a number of respondents to identify events or experiences that were 'critical' for some purpose. These incidents are then pooled together for analysis, and generalizations about the event or activity are drawn from the commonalities of the incidents [...]" (KAIN, 2004, p. 71). This approach aligns with narrative inquiry because the events in question are given preeminence. Citing Tripp, Kain states that critical incidents are not things but are created, interpretations of the significance of an event: "To take something as a critical incident is a value judgment we make, and the basis of that judgment is the significance we attach to the meaning of the incident [...]" (KAIN, 2004, p. 81). Similar to a cartographic process of representing a place, individuals choose what to include in the narration of an event and what to leave out, either intentionally or subconsciously.

\subsection{Critical Cartography}

Drawing on the works of Michel de Certeau and the contemporary geographer Doreen Massey, I entertain various constructs that depict the physical act of traveling as a means of knowing a place. Likewise, these theorists also speak to how this knowledge is then represented, both visually and textually through cartographic processes. Maps have traditionally been known as graphic representations of space (International Cartographic Association (ICA). Critical Geographers additionally speak to what is not represented, as well as the actual ontological and epistemological implications of map-making. Jeremy Crampton claims that

Mapping creates knowledge as much as reflecting it. Critical cartographers do not argue that physical space is produced by the process of mapping, but rather that new ways of thinking about and treating space are produced. For critical cartography, mapping is not just a reflection of reality, but the production of knowledge, and therefore, truth. (CRAMPTON, 2010, p. 46)

The synthesis of these related theories provides a rich lens by which to interpret what the participant captured in their final representation while simultaneously bringing to light that which was not made visible.

\subsection{Map Mashups}

Most participants used a handheld device, such as a smart phone or tablet, that contains the following functionalities: photography, video, audio recording, textual input, GPS location, time stamps, etc. Tom than uploaded the data onto the Google Maps interface to in create his own mashup. Map Mashups originate from a website or program "[...] that combines two or more sources into one tailor-made experience [...]" (CRAMPTON, 2010, p. 27). In 2004, users first began to mix various Open-Source Software (OSS) programs in a way similar to that of musicians who sample two songs to create a third independent track. In 2005, Google Maps revolutionized this practice because users could access its application programming interface (API) and add their own data on top of their 
pre-existing spatial data (BATTY et al., 2010). This new era of Neogeography is a key component of Web 2.0 that facilitates interactive sharing of data. This technology is a visual manifestation of the construct I theorize in terms of how TCs construct a new space through their experiences in urban classrooms.

\subsection{Practicing Space: Michel de Certeau}

The work of Michel de Certeau allows for new interpretations of pre-existing terms such as appropriation, enunciation, other, travel, tourist, home, and consumerism where the act of speaking "[...] establishes a present relative to a time and place; and it posits a contract with the other in a network of places and relations [...]" (CERTEAU, 2002, p. xiii). de Certeau's seminal text The Practice of Everyday Life (1984) posits that everyday life invents itself by poaching in varied ways on the property of others and that basic practices, such as walking or cooking, are means to address epistemological and philosophical inquiries that arise during these events.

Michel de Certeau (2002, p. xxi) advances that reading is the "[...] exorbitant form of contemporary culture $[\ldots]^{\prime \prime}$ for consumption. Similar artistic practices such as photography which involves taking photos mirror this unidirectional consumption and situates the consumer as a voyeur. I have suggested that TC's engage in consumerist practices and theorize TCs at tourists that engage in unidirectional transactions while visiting urban classrooms, which they consider foreign (HETRICK; SUTTERS, 2014).

This modality of reading, or consuming, is then enunciated through the narratives they tell in which the "[...] words become the outlet or product of silent histories. The readable transforms itself into the memorable [...]" (CERTEAU, 2002, p. xxi). Certeau expounds on the writing process in which stories are transported, or poached, and appropriated into a co-opted narrative until "[...] [a] different world (the reader's) slips into the author's place [...]" (CERTEAU, 2002, p. xxi). What is of equal importance is what is not transmitted in the discourse. This process is known as erasure in cartographic discourses and speaks to that which is (un)intentionally forgotten (CRAMPTON, 2010).

\section{Discussion: Narrating Space}

One of the overriding concerns I have with the advent of navigational technology is a decreased necessity to observe the manner in which one arrives at a place in order to return. Between GPS and hand-held devices, we are becoming dependent on a small, flat screen that is empirical and anti-qualitative. As a counter-narrative, I use this technology in coordination with traditional ethnographic processes to recalibrate their sensitivities during their trajectory to and around their placement. This process could be likened to de Certeau's (2002, p. xxii) "[...] ways of frequenting or dwelling in a place $[\ldots]$ an art of manipulating and enjoying $[\ldots] "$.

Tom was raised in what he coined a bizarrely sheltered town that is within walking distance of downtown. The characteristics he uses to describe the inhabitants of his hometown are consistent with the current demographics in teacher education programs at many universities and he shares a 
perspective in his pre-visit questionnaire that is rather accurate in representing many of the TCs I have engaged with:

My graduating class was quite literally $97 \%$ white, with two black students and one Asian in a group of 100 students. Though I live on the less affluent side of town, [town name] is almost unanimously middle-class. In the past few years, as I've reflected on my upbringing, I have often thought of the feeling, or I guess it was more of a lack of feeling, of having almost no desire to leave [town name]; having no reason in my mind to explore other areas of Columbus.

Tom's narration of his upbringing is a rich context to analyze through de Certeau's (2002, p. 79) distinction between reality and the real in that "[...] narrated history creates a fictional space. It moves away from the real - or rather it pretends to escape present circumstances [...]". I want to stress the significance of these constructed narrations that are often left unexamined by students and how the critical incidents experiences at the schools often disrupt their notion of reality in a manner that necessitates reflection and subsequent resolution.

I also want to stress my intentional focus on the participants' point of departure. Too often, site observations focus solely on the destination, the public school setting. The approach I am suggesting places equal significance to the examination of the subjective space that the TC is leaving from with the understanding that this is the construct by which the TC will come to understand the destination through comparison, or difference.

Throughout my experiences with primarily suburban TC's, I have become more cognizant of how ignorant they can be to issues of mobility, transience, and safety. Similar to my own upbringing, many of these students never used public transportation besides the district-funded school buses, lived most of their formative years in one or two places, and lived in relatively safe areas with minimal exposure to dangerous circumstances. As a result, the manner in which they picture urban is often derived from a sheltered perspective. White, suburban, middle-class TCs sometimes have difficulty operating within a different structure and understanding the pedagogical implications of the resultant measures enacted in urban schools.

\subsection{Mapping Space}

The Google Map construct presents a unique platform to synthesize time and place together and it functions effectively as a jumping off point in terms of conducting research about the site and where it is situated in relation to where they are leaving from. Tom's initial comments also reveal some of the limitations Goggle Maps has by way of representing duration and frequency. 
Well, when I started out with the map idea, I think the way that I conceived of it was giving directions. I mean that is sort of how I thought of it. Using Google Maps was like giving directions of how my day goes. I think one of the problems that I ran into was thinking about [...] time, like how it works chronologically. Uhm, I think that is something that, cause I kind of jump around a bit. Like going back into it like after, like there is some entries that we put in the very first day, there are others that I added much later.

A linear, 2-D form of representing place runs parallel to other modernist cartographic process, however the transformation of the temporal to the spatial is of utmost significance as we see evidence of a method where space is given preeminence. The image then is significant in terms of Art Education as de Certeau positions it as the space between doing and writing: "Of all the things everyone does, how much gets written down? Between the two, the image, the phantom of the expert but mute body, preserves the difference [...]" (CERTEAU, 2002, p. 42). I question if there is an interstitial space between places (Urban/Suburban) and if processes (Mapping/Writing/Image-making) associated with representing space happen in a tangible, material place or if it is an imagined, immaterial space. Or, as this study has demonstrated, perhaps the process can be traced visually (mapping) and/or represented through narratives (text).

Tom embraced the Google Map construct and continually made changes to the file after each visit to the school. Interestingly, Tom lived at home so the mapping of his route to the site was a true representation of a daily commute from home. He begins his Google Map by placing a yellow icon of a house at the location he has lived at since 1995. Another unique component of Tom's trajectory is that he is the only one who opted for public transportation. While part of it was out of necessity since he was having car problems, there was a degree of intentionality to his decision since he stated his desire to better understand how taking the bus would impact his understanding of the surrounding community.

Well, uhm that's really interesting because I think like, if you drive a car there you sort of take your environment with you. Uhm, but when you're in a bus, part of your destination is already with you. And so, uhm, really like yeah, it is a very distinct population of folks (choosing his words wisely while insinuating something) that are on the bus, on that bus. And, no one gets off half way through. Everyone is going to [town name]. So it is interesting. Uhm, coming from downtown I guess, I am not really sure exactly where most of the people get on but, so, yeah I think that was something that, I mean, I you know, I have never been on a bus with people like having in-depth conversations or something, but it definitely, kind of put me [...] in a different mindset.

Through an incredibly insightful dichotomy, Tom spatially differentiates what happens when TCs drive to their sites. This study has questioned what TCs decide should be visible and what will be erased. Employing the various tools afforded by Google Maps, Tom visually drafts his walk to the bus 
stop, designates points of transfer with the associated bus numbers, and documents specific times he would leave and arrive at specific points. Because of its' inherently quantitative character, the map allows the viewer to ascertain distance between points as well as receive navigation data such as the length of time required to traverse the distance, but there still are limitations. As Tom stated, he viewed this software as a means of giving directions but encountered problems in accurately reflecting his visitation chronologically. Enacting typical measures associated with surveying a plot, Tom was able to accurately represent the physical dimensions of his trajectory. But where his file excelled in representing place, it failed in documenting space. Tom made a few attempts to include short narratives of his thoughts and observations during his travels, but they were very disjointed and often unrelated to his teaching placement such as when he noticed a guy spitting at a bus stop or his take on a discussion during a morning meeting at church.

The effects of these narratives is what I seek in the data. I believe that in order to attain significant effects, students will need to enter and encounter places that are foreign to what they know. This is where de Certeau's act of walking in the urban system can be employed as a method of transcribing a path or trajectory. In this process, there is a measure of forgetting, or making invisible that which became visible and there also is a triple enunciative function where the topography is appropriated and spatially acted-out through speaking: both processes involve space-making. Through walking, near and far are situated in relation to the participant, as well as an $I$ and an other, thus creating multiple, conjunctive/disjunctive places. De Certeau claims: "To walk is to lack a place. It is the indefinite process of being absent and in search of a proper [...]" (CERTEAU, 2002, p. 103). While this assertion could be seen as limited and overly simplistic, the scenario is effective in establishing what I perceive to contain both place and space. De Certeau eventually defines space as a practiced place and through walking, it is transformed whereas place is subsequently defined as an "[...] instantaneous configuration of positions [...]" (CERTEAU, 2002, p. 117).

However, in Tom's final interview, he provided numerous stories that were clearly informative of his understanding of the site. Since many of them were reiterations of occurrences he had already talked about in either the individual interview or group interview, they emerged as critical incidents. When we were talking about his explorations, I asked him if there was ever any occasions where he felt uncomfortable. He shared a narrative of an encounter he had with someone while waiting for the bus.

I was at the bus stop and uhm, you know [...] and this guy sort of approached me. He was like a White guy, and definitely from that area and he was like talking to me and no one had ever talked to me, no one had ever greeted me, and yeah, this was a while ago. And, I just kind of froze up and didn't know what to do and he was like, 'Are you ok? What's up with you?'.

This narrative shared by Tom was the strongest example of a critical incident throughout the study and one he would refer back to frequently. As he continued to process through the experience, his construction and representation of it resulted in what de Certeau would call effects: 
Narration does indeed have a content, but it also belongs to the art of making a coup: it is a detour by way of a past or by the way of a quotation made in order to take advantage of an occasion and to modify an equilibrium by taking it by surprise. Its discourse is characterized more by a way of exercising itself than by the thing it indicates. It produces effects, not objects. It is narration, not description. It is an art of saying (CERTEAU, 2002, p. 79).

Tom knew he was an outsider and he was able to identify the other as one from that area. As a result of how he was perceived by the man at the bus, Tom began to think critically about his expectations of the area and how his actions directly correlated to what he thought he knew about those that live in it.

Yeah (laughing). It was like, I think I had this idea in my mind that you know I act a certain way in this space, like I had to act like a tough guy or something. Clearly, that's not who I am and I think (laughter) I had this fear of like being myself in that area. Uhm, that was like (laughter) a really humbling experience but after that I really started like being ok with like saying hello to people like I would (laughter) in my part of town. It's silly to me thinking how much I judged the people in that area just by like, oh, I can't say hello to this person, uhm.

I feel Tom struggled with questions such as these while documenting his experiences through Google Maps. Methodologically, Tom's visual presentation was not as dramatic or persuasive as the others. During the final interview, I asked him what the map effectively expresses and what it does not tell about his experiences.

Uhm, I think this gives a good idea of what I brought into the experience, of like what or how, sort of my preconceptions of urban school and like where I am from and how that relates to where I am going, like you know, from my town to this school and things that I am thinking about in terms of race and class issues or whatever. But I think something that it doesn't quite capture is like how uhm, [...] my experience there and like, how things changed from me in the past three months because it wasn't specifically this research that did it but I kind of been, there has been a lot of things happening so I am just you know, and it wasn't on this route (laughter). I think that's something that uh, maybe I tried to show but I don't think it is very clear.

Narrative inquiry effectively aligns with de Certeau's epistemological claims that "[...] everyday stories tell us what one can do in it (room as space) and make out of it. They are treatments of space $[\ldots]^{\prime \prime}$ (CERTEAU, 2002, p. 122). Tom also enacts cartographic terminologies and processes as a means of representing the knowledge -of both space and place - that was acquired during walking. "These narrated adventures, simultaneously producing geographies of actions and drifting into the commonplaces of an order, do not merely constitute a "supplement" to pedestrian enunciations and rhetorics $[\ldots]^{\prime \prime}$ (CERTEAU, 2002, p. 116). 
Again, Tom speaks to that which he took with him but also how he was changed by what he took from the site. He recognized the limitations of the software to convey change, which harkens temporal discourse such as duration. Additionally, the singular route digitally drawn through the software refers to one trip and does not fully encapsulate his ontological presence in a classroom or on a bus or the frequency with which they occurred. In the beginning of this section, I relayed how Tom stated that he encountered problems thinking "how it works chronologically". In summing up his final representation, Tom stated at "this point it's still coherent but it is not exactly how I envisioned it would be in the beginning". Any narrated account of an experience is always going to be lacking, and the story will often be altered with each subsequent telling. Google Maps aided in tracing Tom's experience at his site but clearly was unable to fully replicate the transactions that occurred during his spatial construction, or knowing of the site. It was not entirely how he envisioned it, yet the entire process was instrumental in numerous personal realizations, not only about the site but also about himself.

I do not suggest that Google Maps is an exhaustive means, rather I embrace its' technical limitations as well as its artistic capabilities and as such, I suggest it is an effective tool to use with pre-service Art Education students as the resulting narratives are organic bi-products of the method.

A possibility offers itself for making explicit the relation of theory to the procedures from which it results and to those which are its objects: a discourse composed of stories. The narrativizing of practices is a textual 'way of operating' having its own procedures and tactics [...] a theory of narration is indissociable from a theory of practices, as its condition as well as its production [...]. (CERTEAU, 2002, p. 34)

The practices suggest by de Certeau are helpful in better understanding how narration and mapping can coalesce visually through the Google Map construct and it is at this point where the scholarship of Doreen Massey, a critical geographer, can bolster the aforementioned theories while also suggesting contemporary connections and applications.

\section{Conclusion}

If space is an "[...] ongoing production [...]" as Massey (2005, p. 107) asserts, then there is a connection to movement, or travel, since the body does not remain in a state of stasis; an event necessitates an arrival or movement into a place where an encounter can occur. The question therein is what does one travel through to arrive at a place and how does the place they leave affect how they come to know the place they will occupy. Or is the influence of Bergson more appropriate when Massey claims that "[...] movement visibly consists in passing from one point to another, and consequently in traversing space [...]" (2005, p. 23). She later adds to the discourse of traveling since movement reinforces the implication of space and time by stating, "You are not just traveling through space or across it, you are altering it a little. Space and place emerge through active material practices" (MASSEY, 2005, p. 118). Accepting that space changes over time, this study investigated instances where students became cognizant that being in space changes both it and themselves. 
If mobility (willful, not coerced) is reserved for those with power, I question how travel can be conceived as a way of taming space through imagination (MASSEY, 1994, 2005). Massey is concerned with the way we imagine space and she views space through the lens of a geographer and claims that the problem with conceiving a space is "[...] that it seems to require the drawing of boundaries. Geographers have long been exercised by the problem of defining regions and this question of 'definition' has almost always been reduced to the issue of drawing lines around a place [...]" (MASSEY, 1994, p. 5). Taking into consideration Massey's notion (2005) that space does not have to be seen as unrepresentable, my desire has been to explore the participants' imagined visualizations of space as represented through narratives and mappings. Massey argues that de Certeau's notion of tracing is a representation, not a space and makes similar claims of maps: "Here is a 'space' as a flat surface, a continuous surface. Space as the completed product. As a coherent closed system. Here space is completely and instantaneously interconnected; space you can walk across (MASSEY, 2005). As a process, Massey claims that mapping was a "[...] form of stabilization, or a way of getting one's bearings, making a claim on it - they were hegemonic cognitive mappings [...]" (MASSEY, 2005, p.107). This parallels previous consumerist models of appropriation and expropriation.

So then, I suggest that this method enacts the visual-laden vernacular of cartographic processes without having to fully depend on a closed, material representation such as a map. I inverted the paradigm presented by Massey about the history of maps. "Maps integrate time and space and tell stories while presenting a kind of picture of the world at one moment, they also told the story of its origins [...]" (MASSEY, 2005, p. 107). Conversely, I posit that narratives map-out spatial events. Massey claims that there is always an element of 'chaos' in spatial configurations where "[...] unconnected narratives may be brought into contact or previously connected ones may be wrenched apart [...]. This is the chance of space [...]" (MASSEY, 2005, p. 114). This correlates to de Certeau's referencing of Greek narration as a "diegesis" where the story establishes an itinerary and passes through it. He further states that: "What the map cuts up, the story cuts across [...]" (CERTEAU, 2002 , p. 129). Similar to de Certeau who attempted to invent ways of recapturing the narratives and stories that have been suppressed in the emergence of science, I am interested in how the constructed representations of TCs reveal what emerged during the moment of disruption and what was possibly redrawn or erased in the reproduction of that experience.

During our presentation at the national conference almost a year later, Tom revisited some images from his work and made some current connections with how the experienced informed his current pedagogy. He reflected on how incredibly complex it was at first to describe a "knowing of the space in terms of distinct points along a route". He added that through the mapping process, his "knowledge of the space was constantly being altered and revised as a result of ongoing reflection which traversed multiple aspects of my daily life". It was interesting to see how some distance from the experience has melded with recent experiences to inform his current line of inquiry, one that was continuing to be constructed. He also stated: "What I already thought I knew about this school, along with my knowledge of related spaces along the route, were integral in my coming to know the space, and that this knowledge was always under construction".

Since this study, I continue to make adaptations and implement similar processes with my students in preparation for state licensure. More and more, assessment programs are requiring TCs 
to demonstrate tangible knowledge of the teaching context. As such, this approach has yielded a robust framework to visually represent field observations while also documenting the critical incidents that occurred while at the site.

\section{References}

BALLENGEE-MORRIS, C.; STUHR, P. L. Multicultural art and visual cultural education in a changing world. Art Education, v. 54, n. 4, p. 6-13, 2001.

BASTOS, F. "Tupy or not tupy?": Examining hybridity in contemporary Brazilian art. Studies in Art Education, v. 47, n. 2, p. 102-117, 2006a.

BASTOS, F. Border-crossing dialogues: Engaging art education students in cultural research. Art Education, v. 59, n. 4, p. 20-24, 2006b.

BATTY, M. et al. Map mashups, Web 2.0 and the GIS revolution. Annals of GIS, v. 16, n. 1, p. 1-13, 2010.

CERTEAU, M. DE. The practice of everyday life ( $2^{\text {nd }}$ ed. $)$. Berkeley, CA: University of California Press, 2002.

CLANDININ, D.J.; ROSIEK, J. Handbook of narrative inquiry: Mapping a methodology. Thousand Oaks, CA: Sage Publ., 2006.

CRAMPTON, J.W. Mapping: A critical introduction to cartography and GIS. 1st ed. Hoboken, NJ: Wiley-Blackwell, 2010.

FLYVBJERG, B. Five misunderstandings about case-study research. Qualitative Inquiry, v. 12, n. 2, p. 219-245, 2006.

HETRICK, L.J.; SUTTERS, J.P. Becoming (time) and/or being (space) art teacher: A spatio-temporal look at the culture of student teaching in art education. Journal of Cultural Research in Art Education, v. 31, n. 1 , p. $13-31,2014$.

KITCHIN, R.; DODGE, M. Rethinking maps. Progress in human geography, v. 31, n. 3, p. 331-344, 2007.

MASSEY, D. For space. 1st ed. Thousand Oaks, CA: Sage Publications, 2005. 
MASSEY, D. Space, place, and gender. 1st ed. Minneapolis, MN: University of Minnesota Press, 1994.

MORRIS, C.B.; MIRIN, K.; RIZZI, C. Decolonialization, art education, and one Guarani Nation of Brazil. Studies in Art Education, v. 41, n. 2, p. 100-113, 2000.

SCHWANDT, T.A. The Sage dictionary of qualitative inquiry. 3rd ed. Thousand Oaks, CA: Sage Publ., 2007.

SUTTERS, J.P. Taking Place and Mapping Space: How Pre-Service Art Education Students' Visual Narratives of Field Experiences in Urban/Inner-City Schools Reveal a Spatial Knowing of Place. 2012. Thesis (Doctor in Philosophy) - Ohio State University, Art Education, 2012, Columbus, Ohio, US. Available at: <https://etd.ohiolink.edu/ap/10?0::NO:10:P10_ACCESSION_NUM:osu1345065866>. Accessed: 10 Jun. 2015

SUTTERS, J.P. Travel as a means for the discovery of self. 2006. Thesis - Department of Art Education, Kutztown University, 2006, Kutztown, PA, US. Unpublished Thesis.

Submetido para avaliação em 31 de agosto de 2015.

Aprovado para publicação em 09 de fevereiro de 2016.

Justin P. Sutters - Southern Illinois University Edwardsville, Illinois, Estados Unidos.

E-mail: jpsutters@gmail.com 